Theodoret's People 
TRANSFORMATION OF THE CLASSICAL HERITAGE

Peter Brown, General Editor

I. Art and Ceremony in Late Antiquity, by Sabine G. MacCormack

II. Synesius of Cyrene: Philosopher-Bishop, by Jay Alan Bregman

III. Theodosian Empresses: Women and Imperial Dominion in Late Antiquity, by Kenneth G. Holum

IV. John Chrysostom and the Jews: Rhetoric and Reality in the Late Fourth Century, by Robert L. Wilken

V. Biography in Late Antiquity: The Quest for the Holy Man, by Patricia Cox

VI. Pachomius: The Making of a Community in Fourth-Century Egypt, by Philip Rousseau

VII. Change in Byzantine Culture in the Eleventh and Twelfth Centuries, by A. P. Kazhdan and Ann Wharton Epstein

VIII. Leadership and Community in Late Antique Gaul, by Raymond Van Dam

IX. Homer the Theologian: Neoplatonist Allegorical Reading and the Growth of the Epic Tradition, by Robert Lamberton

X. Procopius and the Sixth Century, by Averil Cameron

XI. Guardians of Language: The Grammarian and Society in Late Antiquity, by Robert A. Kaster

XII. Civic Coins and Civic Politics in the Roman East, A.D. 180-275, by Kenneth Harl

XIII. Holy Women of the Syrian Orient, introduced and translated by Sebastian P. Brock and Susan Ashbrook Harvey

XIV. Gregory the Great: Perfection in Imperfection, by Carole Straw

XV. "Apex Omnium": Religion in the "Res gestae" of Ammianus, by R. L. Rike

XVI. Dioscorus of Aphrodito: His Work and His World, by Leslie S. B. MacCoull

XVII. On Roman Time: The Codex-Calendar of 354 and the Rhythms of Urban Life in Late Antiquity, by Michele Renee Salzman

XVIII. Asceticism and Society in Crisis: John of Ephesus and "The Lives of the Eastern Saints," by Susan Ashbrook Harvey

XIX. Barbarians and Politics at the Court of Arcadius, by Alan Cameron and Jacqueline Long, with a contribution by Lee Sherry

XX. Basil of Caesarea, by Philip Rousseau

XXI. In Praise of Later Roman Emperors: The Panegyrici Latini, introduction, translation, and historical commentary by C.E. V. Nixon and Barbara Saylor Rodgers

XXII. Ambrose of Milan: Church and Court in a Christian Capital, by Neil B. McLynn

XXIII. Public Disputation, Power, and Social Order in Late Antiquity, by Richard Lim

XXIV. The Making of a Heretic: Gender, Authority, and the Priscillianist Controversy, by Virginia Burrus

XXV. Symeon the Holy Fool: Leontius's "Life" and the Late Antique City, by Derek Krueger 
XXVI. The Shadows of Poetry: Vergil in the Mind of Augustine, by Sabine MacCormack

XXVII. Paulinus of Nola: Life, Letters, and Poems, by Dennis E. Trout

XXVIII. The Barbarian Plain: Saint Sergius between Rome and Iran, by Elizabeth Key Fowden

XXIX. The Private Orations of Themistius, translated, annotated, and introduced by Robert J. Penella

XXX. The Memory of the Eyes: Pilgrims to Living Saints in Christian Late Antiquity, by Georgia Frank

XXXI. Greek Biography and Panegyric in Late Antiquity, edited by Tomas Hägg and Philip Rousseau

XXXII. Subtle Bodies: Representing Angels in Byzantium, by Glenn Peers

XXXIII. Wandering, Begging Monks: Spiritual Authority and the Promotion of Monasticism in Late Antiquity, by Daniel Caner

XXXIV. Failure of Empire: Valens and the Roman State in the Fourth Century A.D., by Noel Lenski

XXXV. Merovingian Mortuary Archaeology and the Making of the Early Middle Ages, by Bonnie Effros

XXXVI. Qușayr 'Amra: Art and the Umayyad Elite in Late Antique Syria, by Garth Fowden

XXXVII. Holy Bishops in Late Antiquity: The Nature of Christian Leadership in an Age of Transition, by Claudia Rapp

XXXVIII. Encountering the Sacred: The Debate on Christian Pilgrimage in Late Antiquity, by Brouria Bitton-Ashkelony

XXXIX. There Is No Crime for Those Who Have Christ: Religious Violence in the Christian Roman Empire, by Michael Gaddis

XL. The Legend of Mar Qardagh: Narrative and Christian Heroism in Late Antique Iraq, by Joel Thomas Walker

XLI. City and School in Late Antique Athens and Alexandria, by Edward J. Watts

XLII. Scenting Salvation: Ancient Christianity and the Olfactory Imagination, by Susan Ashbrook Harvey

XLIII. Man and the Word: The Orations of Himerius, edited by Robert J. Penella

XLIV. The Matter of the Gods, by Clifford Ando

XLV. The Two Eyes of the Earth: Art and Ritual of Kingship between Rome and Sasanian Iran, by Matthew P. Canepa

XLVI. Riot in Alexandria: Tradition and Group Dynamics in Late Antique Pagan and Christian Communities, by Edward J. Watts

XLVII. Peasant and Empire in Christian North Africa, by Leslie Dossey

XLVIII. Theodoret's People: Social Networks and Religious Conflict in Late Roman Syria, by Adam M. Schor 



\section{Theodoret's People}

Social Networks and Religious Conflict in Late Roman Syria

Adam M. Schor

甲

UNIVERSITY OF CALIFORNIA PRESS

Berkeley Los Angeles London 
University of California Press, one of the most distinguished university presses in the United States, enriches lives around the world by advancing scholarship in the humanities, social sciences, and natural sciences. Its activities are supported by the UC Press Foundation and by philanthropic contributions from individuals and institutions. For more information, visit www.ucpress.edu.

University of California Press

Berkeley and Los Angeles, California

University of California Press, Ltd.

London, England

(C) 2011 by The Regents of the University of California

Library of Congress Cataloging-in-Publication Data

Schor, Adam M., 1976-.

Theodoret's people : social networks and religious conflict in late Roman Syria / Adam M. Schor.

p. $\mathrm{cm}$.

Includes bibliographical references and index.

ISBN 978-0-520-26862-3 (cloth, alk. paper)

1. Theodoret, Bishop of Cyrrhus-Friends and associates. 2. Christian sociology-Syria-History. 3. Syria-Church history. 4. Antiochian school. I. Title.

$\mathrm{BR} 1720 . \mathrm{T}_{3} 6 \mathrm{~S}_{3} 62010$

$261.0939^{\prime} 4309015-\mathrm{dc2} 2$

2010025774

Manufactured in the United States of America

$\begin{array}{lllllllll}20 & 19 & 18 & 17 & 16 & 15 & 14 & 13 & 12\end{array}$

$\begin{array}{llllllllll}10 & 9 & 8 & 7 & 6 & 5 & 4 & 3 & 2 & 1\end{array}$

This book is printed on Cascades Enviro 100, a 100\% post consumer waste, recycled, de-inked fiber. FSC recycled certified and processed chlorine free. It is acid free, Ecologo certified, and manufactured by BioGas energy. 